\title{
EARLY SIGNS OF DIABETIC NEPHROPATHY AND ULTRASOUND CHARACTERISTICS OF KIDNEYS IN CHILDREN AND YOUTH WITH DIABETES MELLITUS TYPE 1
}

\author{
Hasanovic Evlijana, ${ }^{1}$ Skokic Fahrija, ${ }^{1}$ Colic Belkisa, ${ }^{1}$ Cosickic Almira, ${ }^{1}$ \\ Hajder Midhat, ${ }^{2}$ Imamovic Goran, ${ }^{2}$ Trnacevic Senaid ${ }^{2}$ \\ ${ }^{1}$ University Clinical Center Tuzla, Pediatric Clinic, Tuzla, Bosnia and Herzegovina \\ ${ }^{2}$ University Clinical Center Tuzla, Clinic for internal disease, Tuzla, Bosnia and Herzegovina
}

Primljen/Received 30. 11. 2013. god.

Abstract: Introduction: Diabetic nephropathy is a chronic complication in patients with diabetes mellitus typ 1, which leads to kidney disfunction.

Aim: The aim of this study was to compare the metabolic control and albuminuria with ultrasound findings of morphometric measurements and registration Doppler signals of kidneys between children and youth with diabetes mellitus type 1 according to the duration of illness.

Material and Methods: The retrospective-prospective study included 69 patients of both genders, that got diabetes mellitus type 1 when they were in the age from 2. to 25 . years. Patients were divided into two groups according to the length of diabetes mellitus type 1: the first group was those whose illness had lasted for more than 10 years, and second group with duration of diabetes mellitus typ 1 less than 10 years.

Results: No significant difference was registered between the groups regarding frequency of albuminuria, but the chance of it occurring are greater in patients with longer duration of diabetes mellitus type 1. Patients with albuminuria and diabetes mellitus type $1 \mathrm{du}-$ ration over 10 years had higher glycated hemoglobin A1C, blood pressure, body mass index followed by enlarged volume of both kidneys. Patients with albuminuria and diabetes mellitus type 1 for less than 10 years had a higher creatinine clearance.

Conclusion: Ultrasound dimensions and volume of the kidneys in patients with metabolic control parameters are useful for monitoring especially in the early stages of diabetic nephropathy.

Keywords: metabolic control, diabetes mellitus typ 1 , diabetic nephropathy, albuminuria, ultrasound parameters.
Prihvaćen/Accepted 28. 01. 2014. god.

\section{INTRODUCTION}

Diabetic nephropathy $(\mathrm{DN})$ is a chronic complication in patients with diabetes mellitus typ 1(DMT1), which leads to progressive decay of the parenchyma and kidney disfunction (1). First stage of DN, marked as hypertrophic hyperfiltration, varies in duration, occurs within the first five years after diagnosing DMT1 $(1,2)$. Size of kidneys enlarges $20 \%$, renal blood flow increases 10-15\%, while albuminuria (AER) and blood pressure are within referential values. Second stage of DN is characterized by occurrence of albuminuria (AER) (2). Albuminuria is clinically the first detectible sign of DN and in following years has a tendency to progress into manifested proteinuria. In this stage the size of kidneys and glomerular filtration are elevated with pronounced AER. Blood pressure may be elevated or within normal values. Manifested AER is pronounced in the period of 10-15 years upon diagnosing DMT1 (3). Size of kidneys and glomerular filtration (GF) may be within referential values, but AER and blood pressure are elevated $(4,5)$. In initial stages of DN in children with normal renal function, ultrasound exam showing enlarged dimensions of kidneys in relation to standards may be an early pathomorphological sign of parenchymal kidney lesion. It has been noticed that, besides kidneys, other organs were also enlarged in the initial stage of DM $(1,5,6)$. Maintaining appropriate metabolic control with regular ultrasound examinations of kidneys and controlling AER might affect the appearance of and inhibit the occurrence of progression of DN in children and youth.

The aim of this study was to compare the metabolic control and albuminuria with ultrasound findings of 
morphometric measurements and registration Doppler signals of kidneys between children and youth with diabetes mellitus type 1 according to the duration of illness.

\section{MATERIAL AND METHODS}

The analysis included 69 patients of both genders whose DMT1 occurred when they were in age from 2. to 25. years, and regularly have controls at Endocrinology ambulance in the Clinic for children and Clinic for internal diseases of the University Clinical Center Tuzla (UCC Tuzla). Patients have DMT1 for various lengths of time, they were of different ages when DMT1 occurred. All data of our patients were acquired based on available medical documentation (illness history and medical charts), questionnaire, physical examination and laboratory findings. Data for questionnaires was gathered from parents of patients younger than 18 and from patients themselves if aged over 18, with their consent in accordance with procedure in UCC Tuzla.

The major part of laboratory testing was conducted within previous hospitalizations at the Clinic for children and Clinic for internal diseases, and performed at the Institute for Biochemistry of the Polyclinic for laboratory diagnostics of UCC Tuzla $(4,6)$. AER was determined in native urine via nephelometric method with reagents from Dade Behring Company. Creatinine concentration in urine was determined through auto-analyzer using a kinetic method by Dade Behring Company.

Afterwards, the relation between albumin and creatinine in urine was determined (5). Before the exam, the blood pressure was measured by the patients while sitting and laying down, on both hands, using a mercury manometer instrument. Information about the duration of DMT1 and metabolic control was analyzed from patient's medical history and medical charts.

The clearance of endogenous creatinine was determined through Schwartz equation, and based on Counahan-Barrat equation glomerular filtration (GF). To apply Schwartz equation, values of creatinine clearance, height of the patients and serum creatinine values were necessary, along with constant equations adjusted in accordance with age groups and gender (5).

By employing real-time technique on Toshiba Corevision 350 and Logiq 3 machines and using a multi-frequency convex probe of $3.75 \mathrm{mHz}$, dimensions of both kidneys individually were measured, first in a lying position on the back of patients, and then in the right and left "semi-oblique decubitus-position", also the longitudinal diameter of the kidney, width (expressed in $\mathrm{mm}$ ) were measured, parenchyma echogenity, sinus appearance was monitored and kidney volume in milliliters $(\mathrm{ml})$ was determined $(7,8)$. Analyzed also were dimensions of kidneys, acquired from the maximum longitudinal so-called central medium longest kidney diameter. The width of parenchyma was measured through the previous intersection located at the junction of medial and peripheral third. All values of acquired parameters were compared to the values of nomogram (percentiles) officially used in standard measurements with children, related to decimal age, body height, mass and body surface $(7,8)$. Upon colorization of arterial and vein flux, the Doppler spectrum was monitored on renal and interlobar arteries, and expressed as index of resistens (IR) $(9,10)$. It was compared to official nomograms for children in accordance to decimal age, body height, mass and body surface (9).

Statistical analysis was performed with biomedical application software called "MedCalc for Windows, version 114.4". For statistical significance of value $p$ the usual level of significance, $\mathrm{p}<0.05$, was cho$\operatorname{sen}(11)$.

\section{RESULTS}

The entire sample encompassed 69 patients, 36 (52.17\%) had DMT1 longer than 10 years (first group), and $33(47.83 \%)$ less than 10 years (second group). No statistically significant difference was found in proportions of patients between the both groups $(\mathrm{p}=0.609)$.

From 69 patients, $41(59.42 \%)$ were male and 28 $(40.58 \%)$ were female, with male:female ratio 2.28:1. Male patients were significantly more represented (59.42 vs. $\left.40.58 ; \chi^{2}=4.89 ; \mathrm{p}=0.02\right)$.

Table 1 shows the demographic date of patients with DMT1 related to illness duration. There were statistically significant differences among means of age, and the age when DMT1 occurred in first group, compared to the second group $(p=0.002 ; p=0.004)$. Statistically significant difference was found in the mean of duration of DMT1 in patients in first group compared to patients from second group $(\mathrm{p}<0.001)$. Statistically significant difference in gender distribution in the both groups was not found.

There was no statistically significant difference among the groups considering the frequency of AER ( $p=$ 1.0), but there are greater chances of occurrence of AER in the first group, i.e. with longer duration of DMT1 (> 10 years) $[\mathrm{OR}=1.06295 \%$ CI $(0.413-$ 2.733)], it is shown in Table 2.

Elevated albumin/creatinine (urine) ratio was documented in $18(30.51 \%)$ patients with DMT1 >10 years, while in second group with shorter DMT1 duration ( $<10$ years) it was documented in $16(44.4 \%)$ patients, without significant differences in frequency, as shown in Table 3. 
Table 1. Demographic data of patients with DMT1

\begin{tabular}{|l|c|c|c|c|}
\hline \multirow{2}{*}{\multicolumn{2}{c}{ Demographic date of patients }} & \multicolumn{3}{c|}{ Patients with DMT1 } \\
\cline { 2 - 5 } & $>10$ years & $<10$ years & t-test & - \\
\hline Number & 36 & 33 & - & 0.765 \\
\hline Male/Female & $22 / 14$ & $19 / 14$ & 2.8 & 0.002 \\
\hline Age (years; $\bar{x} \pm$ SD) & $19.2 \pm 4.6$ & $15.3 \pm 5.2$ & 3.3 & 0.004 \\
\hline Age of occurrence DMT1 (years; $\bar{x} \pm \mathrm{SD})$ & $5.8 \pm 4.2$ & $9.5 \pm 5.9$ & 3.0 & $<0.001$ \\
\hline Duration of DMT1 (years; $\bar{x} \pm \mathrm{SD})$ & $13.3 \pm 3.0$ & $5.8 \pm 2.4$ & 11.4 & $<$ \\
\hline
\end{tabular}

DMT1 = diabetes mellitus type 1

Table 2. Frequency of albuminuria in patients according to duration of DMT1

\begin{tabular}{|l|c|c|c|c|}
\hline \multirow{2}{*}{\multicolumn{2}{c|}{ Albuminuria }} & \multicolumn{3}{c|}{ Duration of DMT1 } \\
\cline { 2 - 5 } & $\begin{array}{c}>10 \text { years } \\
\text { N }(\%)\end{array}$ & $\begin{array}{c}<10 \text { years } \\
\text { N (\%) }\end{array}$ & $\chi^{2}$ & $p$ \\
\hline Microalbuminuria & $18(50)$ & $16(48.5)$ & 0.0 & 1.0 \\
\hline Proteinuria & $1(2.8)$ & $1(3)$ & & 1.0 \\
\hline No microalbuminuria & $17(47.2)$ & $16(48.5)$ & 0.0 & \\
\hline Total & $36(100 \%)$ & $33(100 \%)$ & & \\
\hline
\end{tabular}

Table 3. Elevated albumin/creatinine (urine) in patients with DMT1 according to the duration of DMT1.

\begin{tabular}{|l|c|c|c|c|}
\hline \multirow{2}{*}{\multicolumn{2}{c|}{ Diabetic nephropathy }} & \multicolumn{3}{|c|}{ Patients with DMT1 } \\
\cline { 2 - 5 } & $\begin{array}{c}>10 \text { years } \\
\text { N }=36(52 \%)\end{array}$ & $\begin{array}{c}<10 \text { years } \\
\mathrm{N}=33(48 \%)\end{array}$ & $\chi^{2}$ & $\mathrm{p}$ \\
\hline Elevated albumin/creatinine in urine & $18(30.5 \%)$ & $16(44.4 \%)$ & 1.3 & 0.24 \\
\hline
\end{tabular}

$\mathbf{N}=$ number of patients

Table 4. Parameters of metabolic control of patients with albuminuria according to duration of DMT1

\begin{tabular}{|l|c|c|c|c|}
\hline \multirow{2}{*}{\multicolumn{1}{c|}{ Parameters of metabolic control }} & \multicolumn{4}{c|}{ Patients with DMT1 } \\
\cline { 2 - 5 } & $>10$ years & $<10$ years & t-test & P \\
\hline BGL* $(\mathrm{mmol} / \mathrm{l} ; \bar{x} \pm \mathrm{SD})$ & $10.1 \pm 2.0$ & $10.1 \pm 1.4$ & 0.14 & 0.89 \\
\hline HbA1C*(\%; $\bar{x} \pm \mathrm{SD})$ & $11.0 \pm 2.1$ & $9.6 \pm 2.3$ & 2.87 & 0.005 \\
\hline Blood pressure (systolic) $(\mathrm{mmHg} ; \bar{x} \pm \mathrm{SD})$ & $115 \pm 2.3$ & $108 \pm 1.3$ & 15.67 & $<0.001$ \\
\hline Blood pressure $($ diastolic) $(\mathrm{mmHg} ; \bar{x} \pm \mathrm{SD})$ & $80 \pm 0.9$ & $70 \pm 1.7$ & 30.76 & $<0.001$ \\
\hline BMI* $^{*}\left(\mathrm{~kg} / \mathrm{cm}^{2} ; \bar{x} \pm \mathrm{SD}\right)$ & $20.1 \pm 3.3$ & $19.6 \pm 2.9$ & 1.75 & 0.04 \\
\hline
\end{tabular}

* BGL — blood glucose level; HbA1C — hemoglobin A1C; BMI — body mass index

Table 5. Creatinine clearance in patients with albuminuria according to the duration of DMT1

\begin{tabular}{|c|c|c|c|}
\hline \multicolumn{3}{|c|}{ Creatinine clearance $(\mathrm{ml} / \mathrm{min} ; \bar{x} \pm \mathrm{SD})$} \\
\hline $\begin{array}{c}\text { Patients with *DMT1 }>10 \text { years } \\
(\mathrm{N}=36)\end{array}$ & $\begin{array}{c}\text { Patients with DMT1 }<10 \text { years } \\
(\mathrm{N}=33)\end{array}$ & t-test & $\mathrm{P}$ \\
\hline $80.4 \pm 4.5$ & $87.5 \pm 5.5$ & 2.08 & $<0.008$ \\
\hline
\end{tabular}

* DMT1 $=$ diabetes mellitus type 1 
Table 6. Frequency of ultrasounds pathological finding of longitudinal diameter of the right kidney related to DMT1 duration, age and anthropometric parameters in our patients

\begin{tabular}{|c|c|c|c|c|c|c|}
\hline \multirow{4}{*}{$\begin{array}{c}\text { Decimal age } \\
\text { and anthropometric } \\
\text { parameters }\end{array}$} & \multicolumn{6}{|c|}{$\begin{array}{l}\text { *US finding of longitudinal diameter of the right kidney } \\
\text { our patients related to DMT1 duration }\end{array}$} \\
\hline & \multicolumn{2}{|c|}{$>10$ years $(\mathrm{n}=36)$} & \multicolumn{2}{|c|}{$<10$ years $(\mathrm{n}=33)$} & \multirow{3}{*}{ Z } & \multirow{3}{*}{$\mathrm{P}$} \\
\hline & $\mathrm{N}^{*}$ & $\mathrm{P}^{*}$ & $\mathrm{~N}$ & $\mathrm{P}$ & & \\
\hline & $* n(\%)$ & $\mathrm{n}(\%)$ & n (\%) & n (\%) & & \\
\hline Age & $34(49.1)$ & $2(2.9)$ & $29(42.2)$ & $4(5.8)$ & -0.97 & 0.33 \\
\hline Body height & $32(46.2)$ & $4(5.8)$ & $28(40.1)$ & $5(7.9)$ & -0.50 & 0.62 \\
\hline Body mass & $32(46.2)$ & $4(5.8)$ & $32(46.2)$ & $1(1.8)$ & 1.29 & 0.20 \\
\hline Body surface & $32(46.2)$ & $4(5.8)$ & $30(43.6)$ & $3(4.4)$ & 0.28 & 0.78 \\
\hline
\end{tabular}

*US = ultrasound, $\mathbf{N}=$ normal finding, $\mathbf{P}=$ pathological finding, $\mathbf{n}=$ number of patient.

Table 7. Frequency of US pathologic findings of longitudinal diameter of left kidney, related to illness duration, age and anthropometric parameters in our patients

\begin{tabular}{|c|c|c|c|c|c|c|}
\hline \multirow{4}{*}{$\begin{array}{c}\text { Decimal age } \\
\text { and anthropometric } \\
\text { parameters }\end{array}$} & \multicolumn{6}{|c|}{$\begin{array}{l}\text { *US findings of longitudinal diameter of left kidney } \\
\text { our patients related to DMT1 duration }\end{array}$} \\
\hline & \multicolumn{2}{|c|}{$>10$ years $(\mathrm{n}=36)$} & \multicolumn{2}{|c|}{$<10$ years $(\mathrm{n}=33)$} & \multirow{3}{*}{ Z } & \multirow{3}{*}{$\mathrm{p}$} \\
\hline & $\mathrm{N}^{*}$ & $\mathrm{P}^{*}$ & $\mathrm{~N}^{*}$ & $\mathrm{P}^{*}$ & & \\
\hline & $*_{n}(\%)$ & $\mathrm{n}(\%)$ & $\mathrm{n}(\%)$ & $\mathrm{n}(\%)$ & & \\
\hline Age & $34(49)$ & $2(2.8)$ & $32(46)$ & $1(2.2)$ & 0.51 & 0.61 \\
\hline Body height & $32(46)$ & $4(5.7)$ & $32(46)$ & $1(2.2)$ & 1.29 & 0.20 \\
\hline Body mass & $32(46)$ & $4(5.7)$ & $32(46)$ & $1(2.2)$ & 1.29 & 0.20 \\
\hline Body surface & $32(46)$ & $4(5.7)$ & $32(46)$ & $1(2.2)$ & 1.29 & 0.20 \\
\hline
\end{tabular}

*US = ultrasound, $\mathbf{N}=$ normal finding, $\mathbf{P}=$ pathological finding, $\mathbf{n}=$ number of patient.

Table 8. Frequency of US pathologic findings of right kidney volume in relation to duration of DMT1, age and anthropometric parameters in our patients

\begin{tabular}{|c|c|c|c|c|c|c|}
\hline \multirow{4}{*}{$\begin{array}{c}\text { Decimal age } \\
\text { and anthropometric } \\
\text { parameters }\end{array}$} & \multicolumn{6}{|c|}{$\begin{array}{l}\text { *US findings of right kidney volume in relation } \\
\text { to duration of DMT1 in our patients }\end{array}$} \\
\hline & \multicolumn{2}{|c|}{$>10$ years $(n=36)$} & \multicolumn{2}{|c|}{$<10$ years $(\mathrm{n}=33)$} & \multirow{3}{*}{$\mathrm{Z}$} & \multirow{3}{*}{$\mathrm{P}$} \\
\hline & $* \mathrm{~N}$ & $* \mathrm{P}$ & $\mathrm{N}$ & $\mathrm{P}$ & & \\
\hline & $*_{n}(\%)$ & $\mathrm{n}(\%)$ & $\mathrm{n}(\%)$ & $\mathrm{n}(\%)$ & & \\
\hline Age & $33(47.6)$ & $3(4.5)$ & $32(46.5)$ & $1(1.4)$ & 0.94 & 0.35 \\
\hline Body height & $30(43.3)$ & $6(8.7)$ & $32(46.5)$ & $1(1.4)$ & 1.87 & 0.03 \\
\hline Body mass & $30(43.3)$ & $6(8.7)$ & $32(46.5)$ & $1(1.4)$ & 1.87 & 0.03 \\
\hline Body surface & $29(41.8)$ & $7(10.1)$ & $30(43.6)$ & $3(4.5)$ & 1.22 & 0.22 \\
\hline
\end{tabular}

*US = ultrasound, $\mathbf{N}=$ normal finding, $\mathbf{P}=$ pathological finding, $\mathbf{n}=$ number of patient.

Table 9. Frequency of US pathologic findings of left kidney volume in relation to duration of DM T1, age and anthropometric parameters in our patients

\begin{tabular}{|c|c|c|c|c|c|c|}
\hline \multirow{4}{*}{$\begin{array}{c}\text { Decimal age } \\
\text { and anthropometric } \\
\text { parameters }\end{array}$} & \multicolumn{6}{|c|}{$\begin{array}{l}\text { *US findings of left kidney volume in relation } \\
\text { to duration of DM T1 in our patients }\end{array}$} \\
\hline & \multicolumn{2}{|c|}{$>10$ years $(n=36)$} & \multicolumn{2}{|c|}{$>10$ years $(\mathrm{n}=33)$} & \multirow{3}{*}{ Z } & \multirow{3}{*}{$\mathrm{P}$} \\
\hline & $* \mathrm{~N}$ & $* \mathrm{P}$ & $\mathrm{N}$ & $\mathrm{P}$ & & \\
\hline & $*_{\mathrm{n}}(\%)$ & $\mathrm{n}(\%)$ & $\mathrm{n}(\%)$ & $\mathrm{n}(\%)$ & & \\
\hline Age & $33(47.6)$ & $3(4.3)$ & $32(46.5)$ & $1(1.6)$ & 0.94 & 0.35 \\
\hline Body height & $31(44.7)$ & $5(7.2)$ & $32(46.5)$ & $1(1.6)$ & 1.6 & 0.05 \\
\hline Body mass & $31(44.77)$ & $5(7.2)$ & $31(86.1)$ & $2(13.9)$ & 1.6 & 0.05 \\
\hline Body surface & $29(41.8)$ & $7(10.1)$ & $28(40.7)$ & $5(7.4)$ & 0.47 & 0.64 \\
\hline
\end{tabular}

*US = ultrasound, $\mathbf{N}=$ normal finding, $\mathbf{P}=$ pathological finding, $\mathbf{n}=$ number of patient. 
Table 10. Frequency of pathological findings of IR in renal and interlobar arteries of the right kidney in patients with DM T1

\begin{tabular}{|l|c|c|c|c|c|c|}
\hline \multirow{4}{*}{ Artery } & \multicolumn{5}{|c|}{$*$ IR of renal and interlobar arteries of the right kidney } \\
related to duration of DM T1
\end{tabular}

*IR = index of resistence, $\mathbf{N}=$ normal finding, $\mathbf{P}=$ pathological finding, $\mathbf{n}=$ number of patient.

Table 11. Frequency of pathological findings of IR in renal and interlobar arteries of the left kidney in patients with DMT1

\begin{tabular}{|c|c|c|c|c|c|c|}
\hline \multirow{4}{*}{ Artery } & \multicolumn{6}{|c|}{$\begin{array}{l}\text { *IR of renal and interlobar arteries of the left kidney } \\
\text { related to duration of DMT1 }\end{array}$} \\
\hline & \multicolumn{2}{|c|}{$>10$ years $(n=36)$} & \multicolumn{2}{|c|}{$<10$ years $(\mathrm{n}=33)$} & \multirow{3}{*}{$\mathrm{Z}$} & \multirow{3}{*}{$\mathrm{P}$} \\
\hline & $* \mathrm{~N}$ & $* \mathrm{P}$ & $\mathrm{N}$ & $\mathrm{P}$ & & \\
\hline & $*_{n}(\%)$ & $\mathrm{n}(\%)$ & $\mathrm{n}(\%)$ & $\mathrm{n}(\%)$ & & \\
\hline Renal & $28(43.5)$ & $8(11.5)$ & $30(43.6)$ & $3(4.4)$ & 1.49 & 0.14 \\
\hline Interlobar & $28(43.5)$ & 8 (11.5) & $28(40.7)$ & $5(7.3)$ & 1.27 & 0.20 \\
\hline
\end{tabular}

*IR = index of resistence, $\mathbf{N}=$ normal finding, $\mathbf{P}=$ pathological finding, $\mathbf{n}=$ number of patient.

Table 4 provides an overview of statistically significant higher value of glikolizated hemoglobin A1C (HbA1C), systolic and diastolic blood pressure, body mass index (BMI) in patients with AER and DMT1 lasting longer than 10 years, in relation to patients with shorter DMT1 duration. Statistically significant difference in glycaemia between the both groups was not registered.

Statistically significant higher creatinine clearance was present in patients with AER, whose DMT1 has lasted less than 10 years, in comparison to patients who have had DMT1 longer $(\mathrm{t}=2.08 \mathrm{df}=17 ; \mathrm{P}=0.008)$, as shown in Table 5.

Figure 1 shows ROC curve of relation between duration of DMT1 and AER, with calculated duration of DMT1 of 11.6 years in children and youth, time necessary for development of AER. After 11.6 years, 50\% of patients with AER will develop other form of $\mathrm{DN}$, and in the group with no AER, 77\% will not develop DN (12).

Table 6 and 7 present the frequency of ultrasound (US) pathological findings of longitudinal diameter of the right and left kidney in patients with DMT1 > 10 years, related to decimal age, body height, mass and BMI, with no statistically significant difference compared to patients with DMT1 $<10$ years.

The frequency of US pathological findings of the volume of right kidney in the group of patients with DMT1 > 10 years, related to decimal age and BMI, is

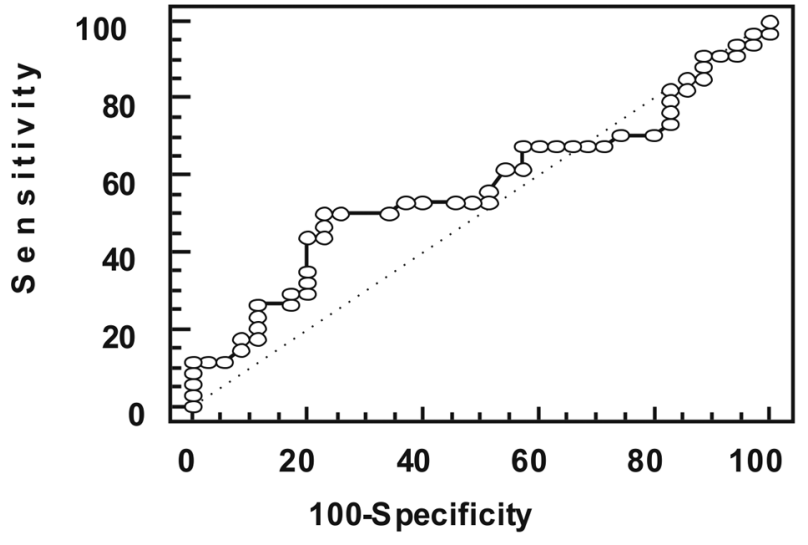

Figure 1. ROC curve of relation between DMT1 duration and microalbuminuria

not statistically significantly different from the second group, while according to body mass and height are a significant different, as shown in Table 8.

Table 9 shows in relation to patients with DMT1, frequency of US pathological findings for left kidney volume is statistically significantly higher for group of patients who have had DMT1 $>10$ years, in accordance to their body height and mass.

Proportion test determined that there is no statistically significant difference in frequency of pathological findings of IR in renal and interlobar arteries in the right and left kidney, in relation to duration of DMT1, as shown in Tables 10 and 11. 


\section{DISCUSSION}

Average age of our patients in the first group was 19.2 years and statistically significantly differed from the age of patients in the second group. DMT1 is the most common illness in elementary school-aged children and over $80 \%$ of children and adolescents is aged under 20 when DMT1 is diagnosed [13]. The average age of occurrence DMT1 in our patients was preschool and elementary-school years, with emphasized statistical difference beetwen the both groups. DMT1 may occur at any age of life, although most patients had it diagnosed in childhood and early adolescence $(13,14)$.

In the group of our patients with AER, statistically significant higher values of $\mathrm{HbA1C}$, systolic and diastolic blood pressure and BMI were found. Inadequate metabolic control directly correlated with kidney hyperfiltration and hyperperfusion. It presents one of the major risk factors for occurrence of AER among children and youth with DMT1 $(15,16)$.

High levels of HbA1C as a marker of chronic hyperglycemia are the most commonly determined risk factor for appearance of AER and development of DN in children and youth with DMT1 (16). Elevated values of systolic and diastolic blood pressure, according to some authors, appear independently from AER $(16,17,18)$. Despite the high prevalence of elevated blood pressure in children with DM and AER, prospective longitudinal studies shows the great influence of other risk factors, especially those that are inherent (17). BMI values above 95 percentiles are noticeable at the onset of DMT1, while after a long time of duration of DMT1, it may occur in children due to irregular or misused insulin therapy (19). Higher or lower BMI values of our patients are possibly explained by various ages during this research.

Duration DMT1 in our children and youth necessary for development of AER was 11.6 years (Figure 1). Sensitivity in one half of our patients will confirm the presence of AER, while higher specificity in three quarters of patients will exclude those who do not have AER (Figure 3). It means that probably $50 \%$ of all patients will show some signs of nephropathy after 11.6 years duration of DMT1. A more reliable evidence is the fact that $77 \%$ of patients will not have AER, after 11.6 years with the illness, but it is possible that they will exhibit certain distorted parameters of metabolic control, such as $\mathrm{HbA1C}$, elevated blood pressure or BMI.

This crucial information, that 11.6 years of DMT1 duration is necessary for development of AER as an early sign of nephropathy, opens up a possibility and chance to detect early morphologic and functional changes on kidneys in ill children and youth before.
For prevention, further progression of DN, development of hypertension and other chronic complications, time period is of essence. This is the so-called intervention point, critical time for prevention of most important risk factors in renal weakening progression: hypertension, infections and distorted metabolic control (20). DN itself and factors of its appearance can not be prevented and can be influenced very little, but side effects, such as infection, hypertension, disturbed metabolic control, as well as obesity, can be regulated with a systematic and scientifically based manner.

Hyperfiltration and kidney hyperperfusion are difficult to determine, so reliable measurement (quantification) of AER remains one of the most reliable tests $(17,19,20)$.

In the research by Turkish authors, AER prevalence was higher in their patients, by whom DMT1 were diagnosed before the age of 15 , but also significantly higher in patients with longer duration of DMT1 (20). Statistically, there was no significant difference between the groups of our patients in frequency of AER ( $p=$ $1.0)$, but chances of AER occurrence are higher in the patients with longer duration of DMT1 $>10$ years. Nowadays, the duration of DMT1, blood pressure, and poor metabolic control are the major risk factors for the development and progression of DN. Some of habits, just as cigarette smoking and eating fast food have big influence to metabolic control and progression DN. Positive family history of renal disease with low socio-economic status with longer duration of DMT1 may accelerate progression of DN. Elevated relation albumin/creatinine in urine does not significantly differ in both groups, while the possibility of occurrence of elevated values of albumin/creatinine in urine is equal in both groups of our patients. Considering the limitations of this study with a fewer number of patients, a more decisive conclusion could be drawn on samples with higher number of patients $(1,16,20)$. Nevertheless, statistically significant lower value of creatinine clearance occurred in our patients with DMT1 $>10$ yeras, related to patients with shorter period of duration DMT1 $(P=0.008)$. Elevated values of creatinine clearance in our patients with shorter DMT1 history can be explained with hyperfiltration in the initial stage of DN $(15,16)$. In the group of our patients who have had DMT1 $>10$ years, longitudinal diameter of both kidneys was not significantly changed in relation to applied standards for age and anthropometry parameters. Other authors as well, in similar research, gathered almost identical results $(9,13)$. A more significant aberration of volume of right and left kidney in relation to standards for body height and mass was found in the group of patients who have DMT1 > 10 years. Enlargement of kidney volume in DM appears with retaining 
salt and water, as well as complex pathophysiological processes on the very small blood vessels $(14,16)$. Enlargement of dimensions and volume of kidneys is one characteristics of DMT1 in the stage of hypertrophic hyperfiltration $(13,16)$.

In our study, no significant differences were noticed in frequency of pathology result for IR in renal and interlobar arteries in the right and left kidney among patients with various length of DMT1. Higher values of IR follow the progression of DN only in clinically manifested and advanced stadia of DMT1 (23). In the stage of hyperfiltration, IR values may be lower than normal. Hyperfiltration, as a hemodynamic change, cannot be diagnosed based only on IR in most patients with DMT1 $(23,24)$. Color Doppler ultrasonography has not proved to be a sensitive method in early stages of detecting complications of DMT1 at the small kidney blood vessels (24). It is difficult to explain that the dimension and volume of kidneys in certain stages of DMT1 change, they enlarge, while Doppler spectrums above blood vessels remain unchanged.

\section{CONCLUSION}

Early lesions of kidney parenchyma with following metabolic control appear after 10 years of duration of diabetes and are rarely registered earlier. More intense surveillance over metabolic control, along with following albuminuria, could be useful for defining optimum time frame for screening and prevention of diabetic nephropathy.

Ultrasound exams of dimensions and volume of kidneys are useful parameters since they can be applied and analyzed with parameters of metabolic control, especially in early stages of DN (hypertrophic hyperfiltration). Changes on blood vessels in early stages of diabetic nephropathy are not clear and evident, so pathologic values could not be registered using Doppler spectrum.
Abbreviations
DN - diabetic nephropathy
DMT1 - diabetes mellitus type 1
GF - glomerular filtration
AER - albuminuria
UCC Tuzla - University Clinical Center Tuzla
ml - milliliters
IR - index of resistens
US - ultrasound
BMI - body mass index
HbA1C - glikolizated hemoglobin A1C

\title{
Sažetak
}

\section{RANI ZNACI DIABETIČKE NEFROPATIJE I ULTRAZVUČNE KARAKTERISTIKE BUBREGA KOD DECE I MLADIH SA DIABETESOM MELITUSOM TIP I}

\author{
Hasanovic Evlijana, ${ }^{1}$ Skokic Fahrija, ${ }^{1}$ Colic Belkisa, ${ }^{1}$ Cosickic Almira, ${ }^{1}$ \\ Hajder Midhat, ${ }^{2}$ Imamovic Goran, ${ }^{2}$ Trnacevic Senaid ${ }^{2}$ \\ 1 Univerzitetski Klinički Centar Tuzla, Dečija Klinika, Tuzla, Bosna i Hercegovina \\ 2 Univerzitetski Klinički Centar Tuzla, Klinika za interne bolesti, Tuzla, Bosna i Hercegovina
}

Uvod: Diabetička nefropatija je hronična komplikacija diabetesa Tip I koja dovodi do difunkcije bubrega.

Cilj: Cilj ove studije bio je poređenje metaboličke kontrole i albuminurije sa ultrazvučnim nalazom mofrometrijskih karakteristika i Doppler signala bubrega medju decom i mladima obolelim od diabetesa Tip I u zavisnosti od trajanja bolesti.

Materijal i metode: Retrospektivno-prospektivna studija obuhvata 69 pacijenata oba pola koji su dobili diabetes Tip I između 2. i 25. godine. Pacijenti su podeljeni u dve grupe prema dužini trajanj bolesti na one kod kojih je bolest trajala duže od 10 godina i one kod kojih je bolest traja manje od 10 godina.

Rezultati: Nije registrovana statistički značajna razlika u postojanju albuminurije ali je šansa o pojavi ista među pacijentima sa dužim trajanjem bolesti. Pacijenti sa albuminurijom i trajanjem diabetesa Tip I dužim od 10 godina imali su veći glikolizirajući hemoglobin HbA1C, krvni pritisak, BMI (body mass index) i volumen oba bubrega. Pacijenti sa albuminurijom i trajanjem diabatesa Tip I manjim od 10 godina imali su veći klirens kreatinina.

Zaključak: Utrazvučne dimenzije i volumen bubrega sa parametrima metaboličke kontrole su korisni za monitoring posebno $\mathrm{u}$ ranim stadijumim a diabetičke nefropatije.

Ključne reči: metabolička kontrola, diabetes melitus Tip I, diabetička nefropatija, albuminurija, ultrazvučni parametri. 


\section{REFERENCES}

1. Rossing P. Diabetic nephropathy: worldwide epidemic and effects of current treatment on natural history. Curr Diab Rep. 2006; 6(6): 479-83.

2. KDIGO 2012 clinical practise guideline for the evaluation and management of chronic kidney disease. Kidney Int Suppl. 2013; 3: 1-150.

3. Amann K, Benz K. Structural renal changes in obesity and diabetes. Semin Nephrol. 2013; 33(1): 23-33.

4. NCCLS. Evaluation of precision performance of clinical chemistry devices. Approved Guideline. NCCLS document EP5-A. Toronto: Wayne; 1999.

5. Schwartz GJ, Muñoz A, Schneider MF, et al. New equations to estimate GFR in children with CKD. J Am Soc Nephrol. 2009; 20(3): 629-37.

6. National Kidney Foundation. Kidney Disease Outcomes Quality Initiative. Clinical practice guidelines for chronic kidney disease: evaluation, classification and stratification. Am J Kidney Dis. 2002; 39(2 Suppl 1): S1-2.

7. Han BK, Babcock DS. Sonografic measurements and appearance of normal kidneys in children. Am J Roentgenol. 1985; 145(3): 611-6.

8. Braun R. Pediatric Ultrasound: How, Why and When. London: British Library Cataloguing; 2005.

9. Rademacher J. Ultrasonography of kidney and the renal vessels: Normal findings, inherited and renoparenchymatous diseases. Part I. Berlin: Der Internist; 2003.

10. Ličanin Z. Dopler Atlas of the extermitets and abdominal vessels: normal anatomy and pathologic findings. Fojnica: Štamparija „Fojnica“; 2002.

11. MedCalc Network statistical software: u [updated 2013 November 22; cited 2013 December 12]. Available from: http: //www.medcalc.org/.

12. Zweig MH, Campbell G.

Receiver-operating characteristic (ROC) plots: a fundamental evaluation tool in clinical medicine. Clin Chem. 1993; 39(4): 561-77.

13. Eurodiab ACE. Variation and trends in incidence of childhood diabetes in Europe. Lancet. 2000; 355: 873-6.

\section{Correspondence to/Autor za korespondenciju}

Evlijana Hasanovic, University Clinical Center, Pediatric Clinic Tuzla

evlijanah@yahoo.com

mobile: +38761887721
14. Claudia Steigleder-Schweiger, Birgit Rami-Merhar, Thomas Waldhör et al. Prevalence of cardiovascular risk factors in children and adolescents with type 1 diabetes in Austria. Eur J Pediatrics. 2012; 171: 1193-202.

15. Aver'ianov AP, Tkacheva EN, Bolotova NV, et al. Preclinical diagnostics and correction of the disturbed renal blood flow in the children presenting with diabetic nephropathy. Rentgenol Radiol. 2011; 5: 25-9.

16. Marcovecchio ML, Chiarelli F. Microvascular disease in children and adolescents with type 1 diabetes and obesity. Pediatr Nephrol. 2011; 26(3): 365-75.

17. Gallego PH, Gilbey AJ, Grant MT, et al. Early changes in 24-hour ambulatory blood pressure are associated with high normal albumin exreation rate in childern with type diabetes mellitus. J Pediatr Endocrinol Metab. 2005; 18(9): 879-85.

18. Basiratnia M, Abadi SF, Amirhakimi GH, Karamizadeh Z, Karamifar H. Ambulatory blood pressure monitoring in children and adolescents with type-1 diabetes mellitus and its relation to diabetic control and microalbuminuria. Saudi J Kidney Dis Transpl. 2012; 23(2): 311-5.

19. Ogden CL, Carroll MD, Curtin LR, Lamb MM, Flegal KM. Prevalence of high body mass index in US children and adolescents, 2007-2008. JAMA. 2010; 303(3): 242-9.

20. Simsek DG, Aycan Z, Ozen S, et al. Diabetes Care, Glycemic Control, Complications and Concomitant Autoimmune Diseases in Children with Type 1 Diabetes in Turkey: A Multicenter Study. J Clin Res Pediatr Endocrinol. 2013; 5(1): 20-6.

21. Beneš-Mirić $S$, et al. Atlas ultrazvučne dijagnostike abdomena. Tuzla: PrintCom; 2002.

22. Braun G, Schwerk W. Ultrashalldiagnostik P diatriche Sonographie III-4 in Lehrbuch und Atlas. Augsburg: Ecomed Buchdruckerei und Verlag Josef Mayer; 2003.

23. Youssef DM, Fawzy FM. Value of renal resistive index as an early marker of diabetic nephropathy in children with type-1 diabetes mellitus. Saudi J Kidney Dis Transpl. 2012; 23: 985-92.

24. Brkljačić B. Dopler krvnih žila. 1. izd. Zagreb: Medicinska naklada, 2000 